\title{
The Development of Scientific Approach-Based Interactive Learning Media of Biology on the Topic of Auditory System for High School Students
}

\author{
Ratna Fadhillah $^{1 *}$, Ely Djulia ${ }^{2}$, Diky Setya Diningrat ${ }^{2}$ \\ 1,2Department of Biology Education, Postgraduate Program, Universitas Negeri Medan, Jl.Willem Iskandar \\ Pasar V Medan Estate-Indonesia (20221)
}

*Corresponding Author: Ratna Fadhillah, Department of Biology Education, Postgraduate Program, Universitas Negeri Medan, Jl.Willem Iskandar Pasar V Medan Estate-Indonesia (20221)

\begin{abstract}
This study aims to find out the level of advisability of scientific approach-based interactive learning media of biology on the topic of "AuditorySystem in Living Things" which was developed in line with Curriculum 2013 so that it was suitable and appropriate applied to all the students of MTs.NegeriLubukPakam. The research method was based on Research and Development(R\&D) adopted from Borg \& Gall. The population of this study consists of six classes of the 204 eighth graders in total. The sample consists of two classes, class VIII-2 amounts 32 students treated as the experimental group and class VIII-5 amounts 32 students treated as the control group as well. The results showed that the interactive learning media were obviously suitable and appropriate to be used in learning process for the eighth students. The result of initial necessity or teacher's perception about the development of learning media showed that the average score was 4,4 and it was categorized as extremely required. The result of percentage score in average from the matter's experts on the learning media approximately 90,77\% and it was categorized as extremely good and the design's experts on the learning media approximately $90 \%$ and it was categorized extremely good. The result of response estimation from five teachers was extremely appropriate about $84,8 \%$ in average.The result of individually tryout from students treated by an interactive learning media was categorized as good about 4,07 in average. The result of small group tryout from students treated by an interactive learning media was categorized as good about 4,14 in average and subsequently the result of limited group tryout from students treated by an interactive learning media was categorized as good about 4,15 in average. The result of hypotheses trial showed that the scientific approach-based interactive learning media which has been developed in line with the Curriculum 2013 on the topic of auditory system in living things and was effective applied to the eighth students in high school. The students' learning outcomes which were taught by Flash-based learning media showed that the average score was higher than taught by PowerPoint-based learning media $(\bar{x} A=92,42>\bar{x} B=84,69)$.
\end{abstract}

Keywords: Interactive Learning Media, Scientific Approach, Auditory System.

\section{INTRODUCTION}

The implementation of education in Indonesia aims to create a qualified generation. Several efforts have been done to achieve the goals of education, by conducting a curriculum improvement. Nowadays Curriculum 2013 is a curriculum that will be a standpoint in Indonesia's learning. Curriculum 2013 has developed a scientific approach with the core activity of learning, namely: observing, asking, attempting, reasoning and communicating (Kemendikbud, 2013)

According to the theory of cognitive aspect, learning is an internal process that includes memory, retention, information management, emotion, and other psychological aspects. Learning also is an activity that involves a very complex thinking process. According to Bruner, the improvement of soemone's cognitive aspect can be increased in the way of arranging learning materials and presenting in line with the level of someone's improvement. This way can develop the ability of a very essential intuitive thought to learn science.

Koballa (2010)has defined science as a way of thinking, a way of investigating, a body of knowledge, and its interaction with technology and society. It could be mentioned that science possesses the dimension of the way of thought, the way of investigation, foundation of knowledge and its 
connection with technology and society. This will be a fundamental substance about the importance of science learning that develops its scientific process on the formation of students' thinking systems.

The learning media of an integrated science with a fascinating scientific approach was required to find the students' comprehension to be more organized and meaningful, and to facilitate students to understand the connection of science matters of one context to others. A good media was an interactive one, so the learning and teaching process would be effective, fascinating and pleasing to students. The use of media could attract students to learn unclear or abstract materials to be more concrete, and difficult materials to be more easily understood (Fathiyati, 2012).

Based on the research of O'day (2007)that the use of animated media has several benefits than the others, the information obtained from animated media would be kept inside someone's long term memory. The animated media could help students visualize an unimaginable process, especially on the unvisualized processes (Betrancourt, 2002). The study of O'day subsequently stated that students' memories who looked at animated media could raise up $87-93 \%$ and would obtain test scores were significantly higher than students who did not look at them. The learning with a technology of interactive multimedia individually was able to make students to be more independent and active in their learning process.

Science teachers at MTs.NegeriLubukPakam have stated the result of daily evaluation tests on the Basic Competence "Understanding the concept of frequency, wave, sound, and hearing, and its application on the auditory system of animals in daily lives was under minimally accomplished criteria, that was $80 / \mathrm{BC}$, this could be seen on the score of the eleventh students' evaluation tests in 2014/2015 (using curriculum of KTSP) on the topic of auditory with the average score of 76 . The eighthstudents in 2015/2016 (C-13) showed that, their average score was 76 on the topic of auditory system in living things. The decrease of students' average scores were due to their misunderstanding of the learning matters that has a teacher delivered.

From the result of questionnaire given to the eighth graders on the type of media used at MTsNegeriLubukPakam showed that of 204 students in total, 56\% or 114 students have stated that they were extremely pleased about motion audio visual, $28 \%$ or 57 students were pleased about picture media, $12 \%$ or 25 students were pleased about printed media, and $4 \%$ or 8 students were pleased about audio media. However, the process of science learning in the field showed that motion audio visual was rarely applied by teachers, but in fact they often applied picture media to students (such as chart\& torso).

The use of computer technology at MTs.NegeriLubukPakam on the learning activity was less optimum, meanwhile the existing computers have possessed programs to create a learning media. The animated media was made on the goal of developing students' potentials and enhancing their learning interests and made them into more interactive and easily to understand the concept of subject materials. The success of a learning process was influenced by several things, including learning material and media (Sudjana, 2009).

This study was undertaken to develop a scientific-based interactive learning media of integrated science on the topic of auditory system in living things, to develop the level of advisability of scientific-based interactive learning media and also to find out the effectiveness of scientific approach-based interactive learning media, so that they could be properly used and applied for students at MTsNegeriLubukPakam.

\section{RESEARCH METHOD}

\subsection{Time and Location of the Study}

This study was conducted at MTsNegeriLubukPakam, located in JalanKaryaAgungKompleksPemkab Deli Serdang, P.O. Box 20515. The research has been conducted in January to May 2017.

\subsection{Research Design}

The research method was based on Research and Development(R\&D) adopted from Borg \& Gall(1983), comprises of 4 phases, namely: Phase I (Research and Information, Collecting andPlanning), Phase II (Develop Preliminary Form Product), Phase III (Preliminary Field Testing), and Phase IV (Dissemination and Implementation). 
The Development of Scientific Approach-Based Interactive Learning Media of Biology on the Topic of Auditory System for High School Students

\subsection{Instruments}

Research instruments wereobservation, interview reports, questionairre reports and documentation as well (Sugiyono, 2016).

\section{RESUltS AND DisCusSion}

\subsection{Results}

\subsubsection{The Result of Initial Necessity or Teachers' Perception}

The result of initial necessity or teacher's perception about the development of learning media from five teachers of Integrated Science at MTs NegeriLubukPakamobtained that the average score was 4,4 as shown in Figure 1.

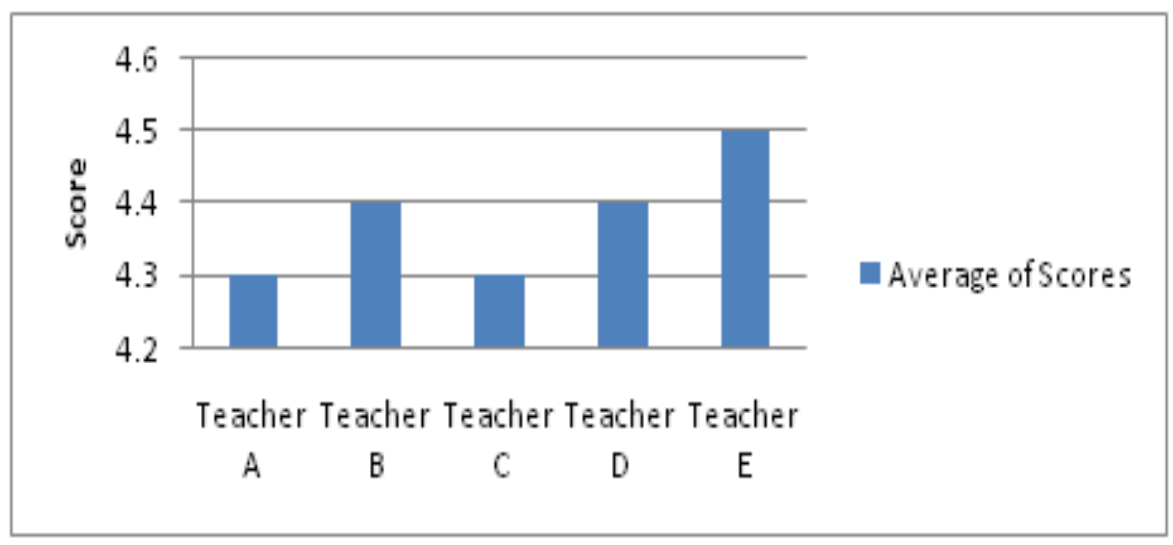

Figure 1. The result of initial necessity of integrated science teachers at MTsN. LubukPakam

Figure 1 showed that there was a high average score of the initial necessity or teachers' perception that tends to be very good.

\subsubsection{The Result of Interactive Learning Media Validated by the Material's Experts}

The result of advisability percentage level of the learning media contents validated by the material's experts on two indicators of the content of learning media product obtained that the average was 90,77\% as shown in Figure 2.

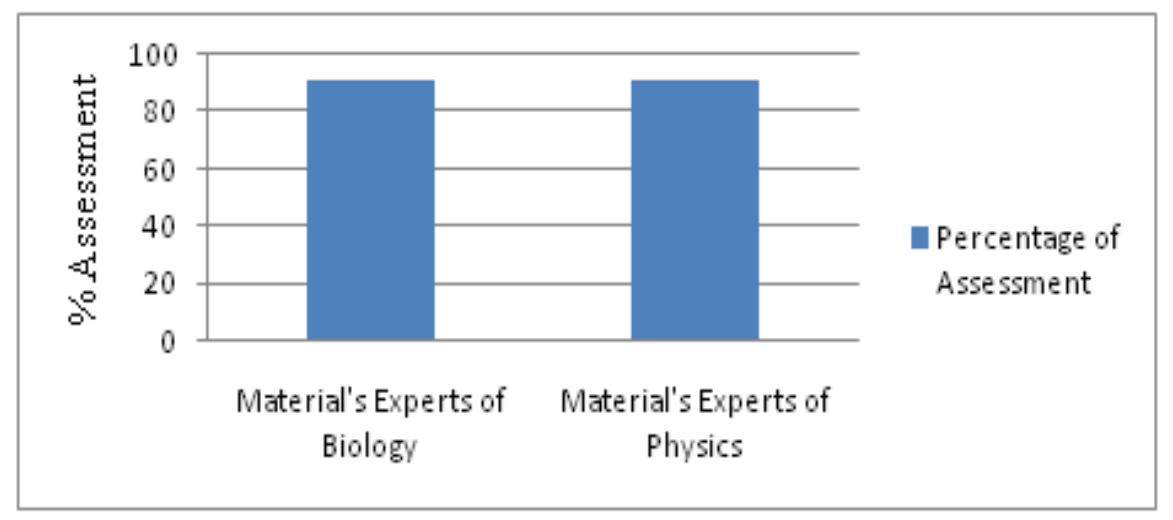

Figure 2. The result of interactive learning media validated by the material's experts

Figure 2 showed that there was a high percentage of estimation that tends to be very good, so that the learning media which has been developed was appropriate to be applied for learning process.

\subsubsection{The Result of Interactive Learning Media Validated by the Design's Experts}

The result of percentage level of learning media design validated by design's experts on the content of product obtained that the average was 90\%as shown in Figure 3.

Figure 3 showed the percentage of estimation indicator of product content was categorized as very good, so that the learning media which has been developed was appropriate to be applied for the learning process. 
The Development of Scientific Approach-Based Interactive Learning Media of Biology on the Topic of Auditory System for High School Students

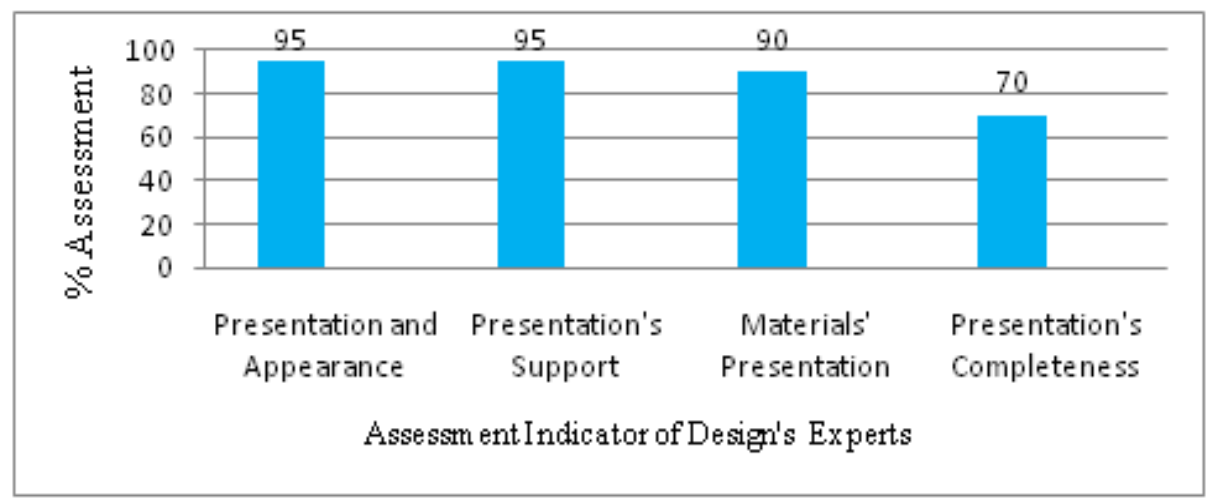

Figure 3. The result of interactive learning media validated by the design's experts

\subsubsection{The Result of Teachers' Responses Estimation on Interactive Learning Media}

The result of advisabilty level of learning media content validated by five teachers on the product of learning media obtained that the average was $84,8 \%$ as shown in Figure 4.

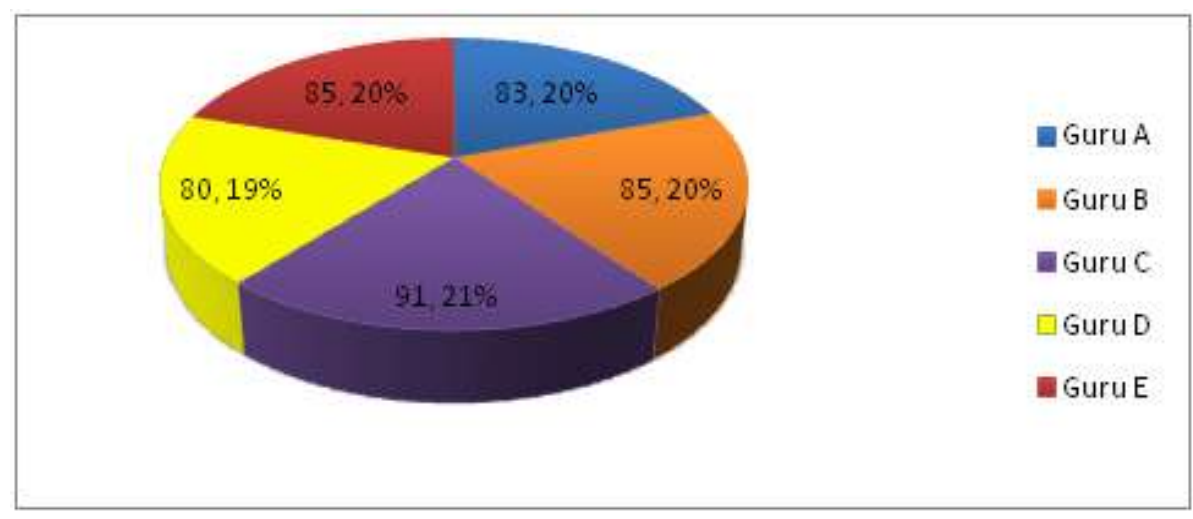

Figure 4. Teachers' responses on interactive learning media

Figure 4 showed that the percentage of advisability level of learning media content tends to be good in a very supportive category, so that the learning media which has been developed was appropriate to be applied and used for the learning process.

The result was in line with the study conducted by Hamdani, et al (2016) that the result of teachers' questionairres obtained from the trial of biology learning media using MacromediaFlash Profesional8was appropriate to be applied with the percentage score of $80 \%$.

\subsubsection{The Result of Students' Responses on Interactive Learning Media}

The trial of learrning materials which has been conducted to the eighth students obtained that the percentage was $73 \%$ in a good criteria, the trial to the small group obtained that the percentage was $86 \%$ in a very good criteria, and subsequently the trial to the limited group obtained that the percentage was $84 \%$ in a very good criteria as shown in Figure 5.

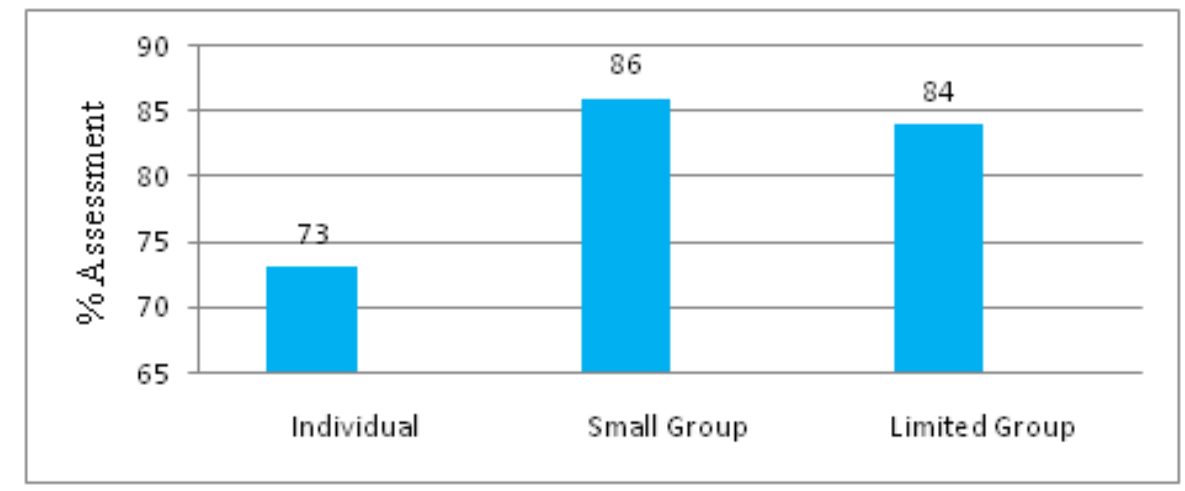

Figure 5. The result of students' responses on interactive learning media 
Figure 5 showed that there was a gain percentage between the individual tryout and small group tryout that tends to be increasing and it means that the learning media was good, and the percentage on the limited group was little decreasing, but overall the learning media was obviously in a very good category.

This was supported by Sudibyo (2005) has also concluded in his study that the whole set of integrated science learning that has been developed could be applied and used well and students would enjoy the learning process by themselves. Aziz andNur (2012) have also stated that the macromedia flash profesional 8-basedBiology learningshowed that students were attracted to that learning media in a response percentage of $43,1 \%$ and it was very good, $46,7 \%$ students mentioned it was good, 10,2\% students mentioned it was quite good, $0 \%$ students chose it was less good and the other $0 \%$ students chose it was not good.

\subsubsection{Effectiveness of The Use of Interactive Learning Media}

The result of hypotheses trial known that $\mathrm{P}=0,000<0,05$ or $\mathrm{H}_{0}$ was rejectedand $\mathrm{H}_{\mathrm{a}}$ was accepted, so it could be explained that the scientific approach-based interactive learning media of integrated science was in line with Curriculum 2013 on the topic of "auditory system in living things" was effective to be used and applied for the eighth students. Students' learning outcomes taught by Flash-based learning media showed that the average score was higher than PowerPoint-based learning media $(\bar{x} A=92,42>\bar{x} B=84,69)$ as shown in Figure 6.

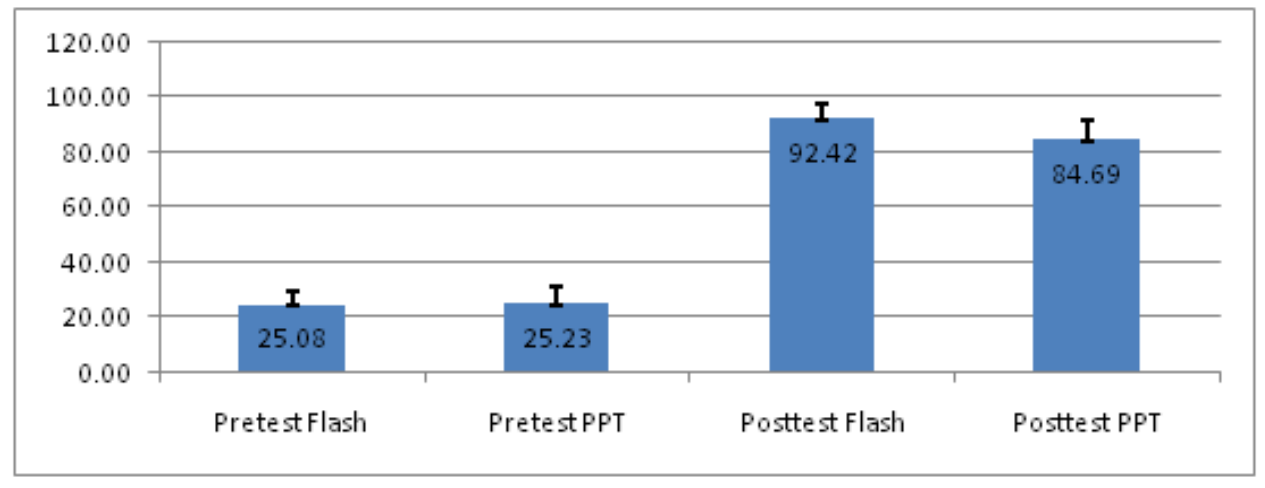

Figure 6. The result of effectiveness of theinteractive learning media usage

The result was in line with the study of Nobina (2012) concluded that the effect of using synchronized multimedia could motivate student's interest to learn and had a positive effect on their academic achievement, between Biology taught by using multimedia and without using multimedia showed the extremely significant difference. Students who were taught by using multimedia showed the average score of 0,51 , higher than students taught by not using multimedia with the average score of 0,23 .

\subsection{Discussion}

In the learning process, media holds the most important thing to achieve the learning goals (Rusman, 2011). This was also strengthened by Daryanto (2010) who stated that the problems often appeared in the use of learning media were the availability and the use of learning media which were rarely applied by teachers. The media often used were textbooks, modules and worksheets. Meanwhile the audio and visual media (such as cassettes, TV/Radio transmission, overhead transparency, video/film), and electronic devices (such as computer and internet) were not intensively applied yet.

This is due to the developed media has a fascinating appearance so that it can give a deep comprehension on the materials and it is very effective to become the learning sources on the topic of auditory system in living things. Learning media also presents the evaluation/exercises, feedback on students' learning performances and find out that students will be encouraged to understand the learning materials. DjamarahandZain (2013) stated that by figuring out the result, students were encouraged to learn more actively, and if that result raised up their learning intensity would be much better.

This was also supported by other previous studies conducted by MustikasariandSupriyanto (2012) concluded that by using Macromedia Flash Profesional 8-based learning media, students would be more active in learning activity and their learning outcomes would achieve the $75 \%$. Furthermore, the 
less of learning media usage will cause students hard to comprehend the learning materials, hence the more students use the learning media the more their self thought and idea will be built instinctively (Arsyad, 2008).

\section{CONCLUSiON}

The development of scientific approach-based interactive elarning media of biology that has been developed in line with the Curriculum 2013 on the topic of auditory system in living things has been suitable with the procedure of Research and Development adopted by Borg \& Gall, through the validation of either material and design's experts, teachers' responses and students' responses (either individual trial, small group and limited group), so that it was appropriate and effective to be used for the eighth students at MTs.NegeriLubukPakam.

The scientific approach-based interactive learning media of biology that has been developed in line with the Curriculum 2013 on the topic of auditory system in living things was effective to be applied for the eighth students at MTs.NegeriLubukPakam. This was shown that students' learning outcomes taught by Flash-based learning media showed the average score of $\bar{x}=92,42$ and taught by PowerPoint-based learning media showed the average score of $\bar{x}=84,69$.

\section{REFERENCES}

[1] Arsyad, A. 2008. Media Pembelajaran. Jakarta: PT. Raja GrafindoPersada.

[2] Aziz, A.A., N. Nur. 2012. Pengembangan Media Pembelajaran Biologi Berbasis Macromedia Flash pada Konsep Sistem Reproduksi Manusia. Jurnal Biomature, 13(2): 83-88.

[3] Betrancourt, M., B. Tversky.,J.B. Morrison. 2002. Animation: Can it facilitate? International Journal of Human-Computer Studies, 57, 247-262. Accessed on January $4^{\text {th }} 2017$.

[4] Borg, W.R.,M.D. Gall. 1983. Educational Research And Introduction. New York. Longman.

[5] Daryanto. 2010. Media Pembelajaran. Yogyakarta: Gava Media.

[6] Djamarah, S.B., A. Zain. 2013. Strategi Belajar Mengajar. Jakarta: Rineka Cipta.

[7] Fathiyati, R. P.U. Runtut. 2012. Pengembangan Media PembelajaranBiologiBerbasis Macromedia Flash SebagaiSumberBelajarBagiSiswa SMA/MA Kelas XI Semester 2 MateriPokokSistemReproduksiManusia. TesisUnimed: Program Pascasarjana UNIMED Medan.

[8] Kemendikbud. 2013. KonsepPendekatanSaintifik. Jakarta: KementerianPendidikandan Kebudayaan.

[9] Koballa. T.R., E.L. Chiapetta. 2010. Science Instruction in the Middle and Secondary Schools: Developing Fundamental Knowledge and Skill. NewYork.(https://coehp.uark.edu /colleague/deanPDF/koballa. Accessed on December $15^{\text {th }} 2016$.

[10] Mustikasari, I., Supriyanto. 2012. Efektivitas Pemanfaatan Macromedia Flash dengan Pendekatan SAVI Materi Sistem Gerak di SMA Negeri 1 Kajen. Unnes Journal of Biology Education, 1(2): 7-13.

[11] Nobina, R. 2012. Pengembangan Media Pembelajaran Multimedia dengan Teknologi Augmented Reality Berbasis Android pada Materi Sistem Respirasi untuk Kelas XI SMA IPA. Jurnal Online UM, 2(1): 1-11.

[12] O'Day, D.H. 2007. The Value of Animations in BiologyTeaching: AStudy of LongTerm Memory Retention.Journal of CBE-Life Science Education, 6: 217-223.

[13] Rusman. 2011. Model-Model Pembelajaran Mengembangkan Profesionalisme Guru. Jakarta: PT. Raja Grafindo Persada.

[14] Sudibyo, E. 2005. Respon Siswa SLTP Khodijah Surabaya terhadap Kegiatan Ujicoba Perangkat Pembelajaran IPA Terpadu. Jurnal Pendidikan Dasar, 6(2): 88-96.

[15] Sudjana. 2009. MetodaStatistika. Bandung: Tarsito.

[16] Sugiyono. 2016. Metode Penelitian Pendidikan, Penelitian Kualitatif dan Kuantitatif ( $R \& D)$. Bandung: Alfabeta.

\section{AUTHORS' BIOGRAPHY}

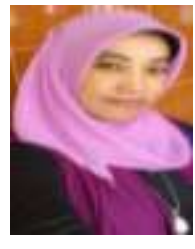

Ratna Fadhillah, M.Pd, is a student of Biology Educationin the Postgraduate Program of UniversitasNegeri Medan (State University of Medan), Medan, North Sumatera, Post Code 20221, Indonesia. She obtained herUndergraduate Degree (S1) in Biology Education from UniversitasIslam Sumatera Utara (Islamic University of North Sumatera), her Master Degree in Biology Education atUniversitasNegeri Medan (State University of Medan). 


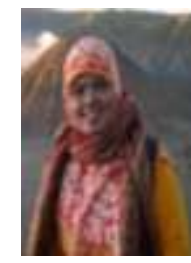

Dr. Ely Djulia, M.Pd, is a Lecturer in the Graduate and Postgraduate Program of Biology Education at UniversitasNegeri Medan (State University of Medan) Medan, North Sumatera, Post Code 20221, Indonesia. She obtained her Bachelor's Degree (S1) in Nature Science Education from IKIP Bandung, her Master's Degree (S2) in Nature Science Education from IKIP Bandung and her DoctoralDegree(S3) in Nature Science Education from UPI (Universitas Pendidikan Indonesia) Bandung.

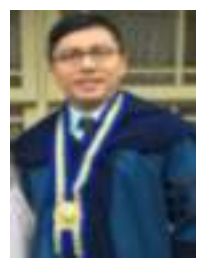

Dr. Diky Setya Diningrat, M.Si, is a Lecturer in the Graduate and Postgraduate Program of Biology Education at UniversitasNegeriMedan(State University of Medan), Medan, North Sumatera, Post Code 20221, Indonesia. He obtained his Bachelor's Degree (S1) in Biology from Institut Teknologi Bandung (Bandung Institute of Technology), his Master's Degree (S2) in Biologyfrom Institut Teknologi Bandung (Bandung Institute of Technology), and his DoctoralDegree (S3) in Biology from Institut Teknologi Bandung (Bandung Institute of Technology).

Citation: Ratna Fadhillah, Ely Djulia, Diky Setya Diningrat. "The Development of Scientific ApproachBased Interactive Learning Media of Biology on the Topic of Auditory System for High School Students" International Journal of Humanities Social Sciences and Education (IJHSSE), vol 4, no. 12, 2017, pp. 127133. doi: http://dx.doi.org/10.20431/2349-0381.0412016.

Copyright: ( 2017 Authors. This is an open-access article distributed under the terms of the Creative Commons Attribution License, which permits unrestricted use, distribution, and reproduction in any medium, provided the original author and source are credited. 